\title{
OKUL ÖNCESİ DÖNEMDE MÜZİK EĞITTIMININ ÖNEMİ
}

\section{The Importance of Music Education In Pre-School Period}

\section{DOI NO:10.5578/amrj.57441}

\author{
Mustafa KABATAŞ ${ }^{1}$
}

\section{Özet}

Sosyal gelişim açısından, çocuğun bulunduğu ortamlara rahat bir şekilde uyum sağlaması, kendini daha cesur bir şekilde ifade edebilmesi için müzik etkinliklerine başvurmanin önemli ölçüde fayda sağladı̆̆ kesindir. Her çocuğun, özellikle kendisini en iyi ifade edebileceği, müziksel etkinlik türünde, gurupla çalışması, onun sosyalleşmesinde çok önemli bir yere sahip olacaktır. Örneğin, gurupla söyleme, sesini kullanmayt ve denetlemeyi keşfedeceği, uyum becerisini geliştireceği, işbirliğine dair disiplin kazanacağı türden bir etkinlikken; bireysel çalgı çalması enerjisini olumlu yönlendirebileceği, kişisel doyum sağlayabileceği ve ritim- melodi duygusunu geliş̧tirebileceği türden bir etkinlik olarak tanımlanmaktadır. Müzik dersinin amaçlarından birisi de zevki eğitmek, çocukta estetik ve artistik zevk yaratmak gibi unsurlardır. Müzikte kalite ve güzelliğin ne olduğunun duyurulmasl, bu unsurlartn duygusal gelişimle bağlantılı olduğunu düşünürsek sağllkl bir duygusal geliş̧im için müzik eğitiminin önemini söylemiş oluruz. Araştırmanın problemini okul öncesi dönemde müzik eğitiminin önemi nasıl olmalıdır? Sorusu oluşturmaktadır. Araştırma: okul öncesi dönemde müzik eğitiminin önemini vurgulaması bakımından okul öncesi eğitimcilerine ve müzik eğitimcilerine kaynak teşkil etmesi amaçlanmıştır. Araştırma okul öncesi dönemde müzik eğitiminin değerini vurgulaması bakımından önemelidir. Araştırmada verilerin toplanmasinda betimsel analiz ve kaynak tarama yöntemi kullanılmıştır.

Anahtar Kelimeler: Okul, Okul Öncesi, Dönem, Müzik, Müzik Eğitimi.

\footnotetext{
${ }^{1}$ Yrd. Doç. Dr., Kastamonu Üniversitesi, Eğitim Fakültesi, Güzel Sanatlar Eğitimi Bölümü, Müzik Eğitimi Anabilim Dalı, mustafa-kabatas@ hotmail.com
} 


\begin{abstract}
In terms of social development, it is the point where it is important to apply music activities so that children are able to adapt themselves to the environment in which they are comfortable and to express themselves in a more courageous way. Each child will have a very important place in socializing, especially in the kind of musical activity in which he can best express himself, working with the group. For example, it is a kind of activity in which you can say with the group, use your voice and discover the control, develop the adaptive skill, and gain discipline about cooperation; It is defined as a kind of activity in which individual instrument play can positively induce energy, provide personal satisfaction and develop rhythm-melody sensation. One of the aims of music lesson is to train taste, to create aesthetic and artistic pleasure in children. If we know what quality and beauty are in music, and if these elements are related to emotional development, we say that music education is important for a healthy emotional development. How should the problem of research be preoccupation of music education in preschool period? It creates the question. Research is important to emphasize the value of music education in the pre-school period. Descriptive analysis and source screening methods were used to collect data in the study.
\end{abstract}

Key Words: School, Pre-school, Term, Music, Music Education.

\title{
GíRiş
}

Okul Öncesi Eğitim, eski çağlardan itibaren, gerekliliğine vurgu yapılan bir kavramdır. İlkçağda Eflatun ve Aristo ile teorik olarak başlayan "çocuğun gelişim özellikleri ve bu özelliklere uygun eğitimi arama çabaları daha sonra Erasmus, Commenius gibi eğitim teorisyenleri ile devam etmiştir (Oktay, 2000: 42).

1800'lü yılların ilk yarısında ise Avrupa'da ortaya çıkan endüstri devriminin, çekirdek aile üzerindeki etkileri nedeniyle, 0-6 yaş arası çocukların bakımı, beslenmesi, korunması vb. ihtiyaçlar nedeni ile de önemli bir sorun olarak ortaya çıkmıştır. Bu sorun okulöncesi eğitimin kurumsallaşmasını hızlandırmış ve Fröbel öncülüğünde açılan "Kindergarten" ile de okulöncesi eğitim kurumsallaşmıştır (Arslan, 2005: 54). 
19. yüzyılın sonu ve 20. yüzyılın başlarında Fröbel'in ortaya koyduğu, eğitimde bireysel farklılıkları dile getirdiği, "eğitimin ilgi ve istekler doğrultusunda, özgürlük ortamında uygulanması gerekir" (Oğuzkan ve Oral, 1991: 26) görüşü çerçevesinde, bu alanda ortaya konulan teorik çalışmalar ve sınırlı da olsa pratik eğitim denemeleri, daha sonra değişik ülkelerde, benzer okulöncesi kuramlarının açılmaya başlamasına neden olmuştur. 20. yüzyılda Piaget'in, "çocuğun zihinsel gelişimine yönelik ortaya koymuş olduğu bilimsel çalışmalarının, yine 20. Yüzyılın başlarında sosyal bilimler alanında yapılan araştırmalara öncülük etmiş, okulöncesi eğitime yönelik bakış açısı ve tanımlamaları geliştirerek, özellikle Avrupa ülkelerinde 1960'h y1llarda okulöncesi eğitiminin genişlemesi ve yaygınlaşmasını sağladığı belirtilmektedir (Aral, Kandır ve Yaşar, 2003: 18).

Çağdaş eğitim anlayışında birey, bedensel, devinişsel, duyuşsal ve bilişsel yapılarıyla bir bütün olarak ele alınıp her alanda da dengeli bir şekilde eğitilmelidir (Uçan, 1984: 51 Akt: Çilden, 2001: 1).

Okullarda verilmeye çalışlan eğitimle çocuklarımız bir bütün olarak ele alınmalıdır. Okulda eğitim ve öğretimin asıl amacı öğrencinin bütün yönlerinin, yani bütün kişilik özelliklerinin en son sınırına kadar geliştirilmesidir. Dersler bunu kısmen yapar. Bundan başka, öğrencinin daha kimi etkinliklerle "yaşantı" kazanması gerekir. $\mathrm{Bu}$ yaşantılar, derslerin erişemediği noktalara girerek bireyi çeşitli yönlerden geliştirecektir (Binbaşıŏlu, 1983: 208 Akt: Çilden, 2001:3). Yaşantı; bireyin belli bir düzeydeki etkileşimleri sonucunda bireyde kalan izdir (Senemoğlu, 1998: 96 Akt: Çilden, 2001: 3).

İlköğretimde çoğu zaman yapılamayan müzik derslerinde çocuğun bu boyutu geliştirilebilir. Ancak etkin müzik öğreten herkesin çocuğu tanıması ve onun gelişimsel özelliklerini bilmesi gerekir. İyi bir eğitim sürecinde, her çocuğun dengeli gelişimini gerçekleştirebilmesi için kendi çabalarına yardımcı olunması ve her çocuğun diğer çocuklardan bazı yönleriyle farklı olduğunun kabul edilmesi gerekir. $\mathrm{Bu}$ nedenle öğretim programları uyarlanabilir ve esnek olmalıdır.

\section{Çocuk ve Müzik}

Çocuklar her türlü materyalden elde edilen sesleri kullanma, deneme, öğrenmeye gereksinim duyarlar. Çocukların melodik kavramları, yetişkinlerinkinden farklıdır ve yetişkinlerin standartlarına göre değerlendirilmemeleri gerekir. Okul öncesi çocuk öncelikle 
seslerle ilgilenir, neyin hangi sesi çıkardığını merak eder. Müzik çocuğun yaşamının bir parçası olmalıdır. Eğer müzik çocuklar için bir dil olacaksa onu kullanmaları gerekir. Yapılan araştırmalar, çocuklara ritm çalışması yapan öğretmenlerin, bu çalışmaların, öğrencilerin sadece uygun zamanda uygun ritmi vermesinin geliştirilmeye çalışılması olmadığı, öğrencinin ritmik etkiye karşı kendi fiziksel tepkisini ortaya koyabilme özgürlüğünün de ritim çalışmaları sırasında verilmeye çalışılması gerektiğinde birleştiklerini ortaya çıkarmıştır (Nye, 1967: Akt: Çilden, 2001: 4 ).

\section{Çocuk Gelişimine Müziğin Katkıları}

Çocuk başka şeylerin yanı sıra, güvenlik hissi, grup içinde yer edinebilme, bir etkinlikte yer alabilme ve kendi sorunlarıyla yüzleşme ve başarılı olmaya gereksinim duyar. Müzik programı, müzik deneyimlerinin kalitesiyle, programın düzenlenmesi ve ele alınan müzik öğretim yöntemleriyle birlikte çocuğun gelişimine katkıda bulunur. İyi hazırlanmış bir müzik eğitimi programıyla çocuk; yaşamın zevkini ve anlamını, sınıf içinde, toplumda, dünyada yaşamayı anlayabilir. Ulusal ve dünya tarihini anlamlı k1labilir. Bilim, sanat, sosyal bilimler, sağlık, din gibi alanlara ilgiyi geliştirip bilgilendirilebilir. Yaratııılığı, değişik tür aktivite düşünceleri geliştirilebilir ve davranışlarında olumlu gelişmeler sağlanabilir.

\section{Araştırmanın Problemi}

Araştırmanın problem cümlesini okul öncesi dönemde müzik eğitimi ne boyuttadır? Okul öncesi dönemde müzik eğitimini iyileştirmek için neler yapılmalıdır? Sorularının yanıtları oluşturmaktadır.

\section{Araştırmanın Amacı}

Okul öncesi dönemde müzik eğitiminin önemini vurgulamas1, nitelikli şekilde yapılmasının ne derecede önemli olduğu, vurgulanmış okul öncesi eğitimcilerine ve müzik eğitimcilerine kaynak teşkil etmesi amaçlanmıştır. 


\section{Araştırmanın Önemi}

Araştırma okul öncesi dönemde müzik eğitiminin öneminin kavranması, okul öncesi eğitimcilerine ve müzik eğitimcilerine bakış açısı kazandırması açısından önemlidir.

\section{YÖNTEM}

Okul öncesi müzik eğitiminde müzik eğitiminin önemini vurgulamak için kaynaklar taranarak hazırlanmış, nitel araştırma yaklaşımına uygun, betimsel tarama modelindedir. Nitel çalışmalar, doküman inceleme, araştırılması hedeflenen olgu ve olaylar hakkında bilgi içeren yazılı materyallerin çözümlenmesini kapsar (Yıldırım ve Şimşek, 2006:187-189). Tarama modeli ise, "geçmişte ya da halen var olan bir durumu olduğu şekilde betimlemeyi amaçlayan yaklaşımdır" (Karasar, 2006: 77).

\section{BULGULAR VE YORUMLAR}

Ülkemizde kuramsal erken çocukluk eğitimi uygulamalarının başlangıcı olarak, Osmanlıda, Fatih Sultan Mehmet zamanında açılan, "Sibyan Mektepleri"' gösterilmektedir.) Bu okullarda çocuklar 4-5 yaşlarında "Âmin Alayı " denilen tören ile ilk okula başladıkları görülmüştür (Akyüz, 1994: 72).

Kitle öğretimi yapan Sıbyan Okullarının, İmparatorluğun parlak devrinde zamanın ihtiyaçlarına cevap verebildiği belirtilmiştir. Osmanlı döneminde 1913 - 1917 yılları arasında, yerli halk için olmamakla birlikte azınlıklar ve yabancılar için büyük kentlerde, imparatorluk sınırları içerisinde resmi anaokullarının açıldığı görülür (Aral, Kandır ve Yaşar, 2003: 18-20).

Yine Osmanlı döneminde, Emrullah Efendi'nin nazırlığında, 1913 yılında çıkarılan "Tedrisat-1 İptidaiye Kanunu Muvakkati" (Geçici İlköğretim Kanunu) ile anaokullarının, ülkenin her yerine yaygınlaştırılması emredilmiştir. $\mathrm{Bu}$ kanunda Ana Mektepleri ve Sıbyan Sınıflarının ilköğretime bağlı olduğu belirtilmiştir. Tedrisat-1 İptidaiye Kanununda adı geçen "Ana Mekteplerine öğretmen yetiştirmek üzere ise 1915 yılında İstanbul'da "Ana Öğretmen Okulu" açılmıştır (Aral, Kandır ve Yaşar, 2003: 24). 
Öğretim süresi bir yıl olan bu okulda, Türkiye'de ilk olarak okul öncesi eğitim alanı için öğretmen eğitimi çalışmaları başlamış ancak 370 kadar mezun veren bu okul 1919 yılında kapandığ belirtilmiştir. Osmanlı döneminde, kadının iş hayatında fazlaca yer almaması, çocukların bakım ve eğitiminden kadınların sorumlu olması, açılan okulların paralı olması nedeniyle okul öncesi eğitim kurumlan yayımlanamadığı görülmüştür. Günümüze bakacak olursak, okul öncesi eğitim kurumlan, birçok bakanlık ve aynı bakanlıkta farklı genel müdürlüklere bağlı olarak faaliyet göstermektedir. 1992'de ilköğretim bünyesinde yer almaya başlayan anasınıfları, okul öncesi eğitimin de son aşamasıdır "Okul Öncesi Genel Müdürlügü 3797 sayılı kanunla" 1993 yllında kurulmuştur (MEB, Tebliğler Dergisi, 2002).

Çalışmamızın planlama ve uygulama aşamasında, MEB Okulöncesi Eğitim Kurumlan Yönetmeliği'ne göre, okulöncesi eğitim 37-72 aylık çocukların eğitimini kapsarken, "21-07 2012 tarih ve 28360 sayılı değişiklikle" bu tarihten itibaren, 33-66 ay arası çocukların eğitimini kapsamaktadır. Anasınıfı ise 60 - 72 ay çocuklarının eğitimini içerirken, aynı tarih ve sayılı değişiklikle, "48-66 ay" arası çocukların eğitimine yönelik olarak değiştirilmiştir. Okul öncesi eğitimin amaç ve görevleri, milli eğitimin genel amaçlarına ve temel ilkelerine uygun olarak şu şekilde sıralanmaktadır:

1. Çocukların beden, zihin ve duygu gelişmesini ve iyi alışkanlıklar kazanmasını sağlamak;

2. Çocukları ilköğretime hazırlamak;

3. Şartları elverişsiz çevrelerden ve ailelerden gelen çocuklar için ortak bir yetiştirme ortamı yaratmak;

4. Çocukların Türkçeyi doğru ve güzel konuşmalarım sağlamaktır" (MEB, Tebliğler Dergisi, 2002).

$\mathrm{Bu}$ ilkeler doğrultusunda, anasınıfı programlarının içeriğini incelediğimizde, yapılandırılmış grup etkinlikleri (Türkçe dil, oyun, fen ve doğa, matematik, drama, okuma yazmaya hazırlık) yanında, müzik etkinlikleri de yer almaktadır. "Müzik etkinlikleri, günlük eğitim programında bulunan tüm etkinliklerin içerisinde kullanılabilen bir araçtır" (Oğuzkan ve Oral, 1991: 34).

Örneğin toplanma ve temizlikte, el y1kamaya giderken temizlikle ilgili bir şarkı söylenebileceği gibi drama da çocukların ilgisini çekmek amacıyla ritmik saymacalar ve ritmik/melodik tekerlemeler kullanılabilir. Ayrıca müziğin, çocuk eğitiminde araç 
olarak kullanılması, çocuğa temel müzik becerisinin kazandırılmasının yanında estetik duyularının geliştirmesi de okul öncesi dönemde müzik eğitiminin hedeflerindendir. Şarkı söyleme ve ritm etkinliklerinin tüm etkinlikleri desteklediği, öğrenilenleri anımsattığı, pekiştirdiği, çocuğun ilgisini konuya yönlendirdiği, öğrenmeyi kolaylaştırdığı belirtilir. Bunların yanı sıra, Artan ve Balat'ın (2001: 356) ifade ettiği gibi: şarkı söyleme çalışmaları ile çocuk Sesini doğru kullanmayı, zamanlamayı, işbirliğini öğrenir. Araştırmacılar tarafından, okulöncesi dönemde müziğin, normal veya özel eğitim gereksinimi olan tüm çocukların eğitiminde kullanılması, bilişsel ve dil, zihinsel gelişim ve yaratıc1lik, duygusal ve sosyal gelişim, bedensel ve psiko-motor gelişim gibi tüm gelişim alanlarını destekleyen ve olumlu etki ettiği vurgulanan önemli araçlardan biri olduğu ifade edilir. Ayrıca küçük yaşlardan itibaren müziksel aktivite içinde bulunarak müzikle beslenen ve desteklenen çocukların ruhsal ve bedensel yönden daha sağlıklı bir gelişim sergiledikleri dile getirilmektedir. $\mathrm{Bu}$ düşüncelerden yola çıkarak, müziğin gelişim alanları üzerindeki etkilerine bakacak olursak, bilişsel gelişimin bir unsuru olan matematik yeteneğinin, müzik eğitimi ile destekleyerek önemli ölçüde geliştirilebileceğine dair çeşitli görüşler bildirilmiştir. Bu bağlamda bu durumu Karşal (2005: 48), "Gerek arka plan müziği olarak kullanılan müzik, gerekse müzik eğitimi kişilerin bilişsel performanslarını dolayısı ile matematik performanslarını geliştirmektedir.” şeklinde ifade etmiştir. Müziğin matematik becerilerini desteklediği ile ilgili olarak pek çok araştırma yapılmıştır. Araştırmacılar küçük çocuklarda, ileri matematik çalışmaları yapılamayacağı fakat onlara çok hoşlanacakları için müzik dinletmenin de yüksek beyin fonksiyonlarını sağlayacağını belirtmektedirler. Çocuğa, tercihen okulöncesi dönemden başlayarak, okullarda verilen müzik eğitiminin, onun uzamsal temporal akıl yürütmesini, dolayısı ile de ileride matematik performansını olumlu etkileyeceği ifade edilmektedir. İnsanın doğuştan işitsel algı, dil ve konuşma yeteneğiyle doğduğu bilinir. Çocuk önce çevresindeki sesleri dinler, bunları anlamaya ve benzerini çıkarmaya çalışır. Ardından kendisini anlatmak ve çevresini anlamak için sözcükleri kullanarak cümleler kurar. Sesler, çocuğun diş dünya ile ilk iletişim aracıdır. Çocukta dil gelişiminin okul öncesinde gerçekleştiği ve bu gelişimde müziğin çok önemli bir yere sahip olduğu kaynaklarda belirtilir. $\mathrm{Bu}$ gelişimi destekleyen en güzel araç ise şarkılar ve tekerlemelerdir. Sözleri, dili ve duyguları geliştirici olan, ezgileri uygun ses aralığında yazılmış, söz-müzik cümleleri uyumlu (prozodisi başarılı), doğru vurgulamalarla söyletilen şarkılar ve tekerlemelerin dil gelişiminde 
önemli olduğu söylenebilir. Müziğin, dil gelişimini hedefleyerek, bir öğretim aracı olarak kullanılmasında da öğretmenin öğrenciye, diksiyon vb. yönlerden doğru model olması gerektiği söylenebilir. Çocukların dil gelişimi açısından işitsel uyarımların, belli hedefler amaçlanarak verilmesi gerektiğini, Bilir, Bal ve Artan (1993: 76), "Çocuğun dili kazanmasında ve kullanmasında, işitsel uyarımların önemli derecede etkisi vardır. Eğitimde; ritm kavramının gelişimi, ses ile kaynağını eşleştirebilme, sesin yönü, uzaklı̆̆ını ayırt edebilme, ses kaynağını isimlendirebilme, işittiği sese ait sözel ifade kullanabilme, şarkı dinleyebilme, şarkıyı drama ile ifade etme, sesin ritmine uygun hareket edebilme, müzik eşliğinde serbest dansla çeşitli ritimleri yorumlayabilme, kavramları müzik aracılığı ile kazanabilme, amaçları göz önünde bulundurulmalıdır" bu sözleriyle ifade etmişlerdir. Sosyal gelişim açısından, çocuğun bulunduğu ortamlara rahat bir şekilde uyum sağlaması, kendini daha cesur bir şekilde ifade edebilmesi için müzik etkinliklerine başvurmanın önemli ölçüde fayda sağladığı belirtilir. Her çocuğun, özellikle kendisini en iyi ifade edebileceği, müziksel etkinlik türünde, gurupla çalışması, onun sosyalleşmesinde çok önemli bir yere sahip olacaktır. Örneğin, grupla söyleme, sesini kullanmayı ve denetlemeyi keşfedeceği, uyum becerisini geliştireceği, işbirliğine dair disiplin kazanacağ1 türden bir etkinlikken; bireysel çalg1 çalması enerjisini olumlu yönlendirebileceği, kişisel doyum sağlayabileceği ve ritim- melodi duygusunu geliştirebileceği türden bir etkinlik olarak tanımlanmaktadır. Müzik dersinin amaçlarından birisi de zevki eğitmek, çocukta estetik ve artistik zevk yaratmak gibi unsurlardır. Müzikte kalite ve güzelliğin ne olduğunun duyurulmas1, bu unsurların duygusal gelişimle bağlantılı olduğunu düşünürsek sağlıklı bir duygusal gelişim için müzik eğitiminin önemini söylemiş oluruz. Dünyanın birçok ülkesinde duygusal bozukluğu olan çocukların tedavisinde müzik terapisinin kullanıldığını bilinmektedir. Çocuğun duygusal gelişiminde müziğin önemini anlatmak için, Kamacıŏglu'nun (1990: 123), Kodaly ile ilgili, Kodaly, meslekten müzikçi olmak için değil, daha iyi ve daha mutlu bir insan olmak için her çocuğun müzik eğitiminden geçmesi gerektiğine yürekten inanıordu. sözünden bahsetmek gerekir. Gelecekte, toplumda yetişkin birey olarak yer alacak olan çocuğun, sağlıklı duygusal gelişimi açısından bakıldığında, çocuğun bulunduğu ortamlara rahat bir şekilde uyum sağlaması, kendini cesur bir şekilde ifade edebilmesi için müzik etkinliklerine başvurmanın, önemli ölçüde fayda sağlayacağını söyleyebiliriz. Müzik etkinliklerinde grupla çalışmak, çocuğun sesini kullanmasını, denetlemesini keşfedeceği, uyum becerisini geliştireceği, işbirliğine 
dair disiplin kazanacağı, sosyal kimliğini kuvvetlendireceği türden bir etkinlikken; bireysel çalg1 çalması, enerjisini olumlu yönlendirebileceği, kişisel doyum sağlayabileceği ve ritm melodi geliştirebileceği türden bir etkinlik olarak tanımlanabilir. Çocukların sosyal gelişiminin en önemli unsurlarından olan çevre eğitimi de müzik yoluyla desteklenebilir. Sungurtekin, (2001: 178), çalışmasında; "Öğretmenler kendi yaratıcılıklarını kullanarak, müzik yoluyla çevre eğitimini farklı boyutlarda verebilirler" demiştir. Buradaki amaç, öncelikle çocuğun çevresinin farkında olabilmesidir denilebilir. Gelecekte daha kaliteli ve temiz bir çevrede yaşamak ve 21 . yüzyılda çevre sorunlarını minimuma indirebilmek için, okullarda müzik eğitimi ile çevre bilinci oluşturulup, bilinçli bir nesil yetiştirilmesi amaçlanması düşünülebilir.

Bebeklikten itibaren işitsel alg1 eğitimi ile başlayan müzik eğitimi, çocukların konuşmasında, kavramları öğrenmesinde, vücudunu koordineli bir şekilde kullanmasında etkili olduğu. Seslerin, doğumundan itibaren çocuğu, devinimlere yönlendirdiği bilinmektedir. Şarkılardaki soluk belirteçlerine göre nefes alma, solunum kontrolünü ve akciğer gelişimini sağlayabileceği gibi; çalgılarla çalışma, hem büyük ve küçük kasların gelişimini hem psiko-motor gelişimini olumlu etkilediği kaynaklarda belirtilmektedir. Bu etkinliklerin gurup içinde sürmesi gelişimi hem hızlandıracağı gibi hem de iletişim becerilerine yeni bir pencere açacağı söylenebilir. Çocuk ilk yaşlardan başlayarak el ve ayaklarıyla tartımsal devinimler yapar. Ezgileri tekrarlayamaz, fakat müziğe uyarak tempo tutmaya, dans etmeye çalışır. Çocukların bedensel gelişimlerine katkı sağlamak amacıyla, müzikten yararlanmak, kaynaklarda geçtiği gibi kaçınılmazdır. Oyunların içinde kullanılacak müziğin hem oyuna katılım isteğini arttıracağını hem de oyunu daha zevkli hale getireceğini söylemek mümkündür. Oyun yöntemi ile kazandırılmak istenen davranışlar, böylece daha kolay kazandırılma imkânına sahip olacaktır denilebilir. Yaratıcılığın, doğuştan itibaren her bireyde bulunabilen ancak sürekliliği, gelişimi, derecesi ve ortaya çıkışı bireysel farklılık gösteren bir yetenek, günlük yaşamdan, bilimsel çalışmalara kadar uzanan, geniş bir alanı içine alan süreç olduğu belirtilir. Müziksel yaratıcılık sürecine baktığımızda, çocukların çok küçük yaşlarda seslere ilgi duymaya ve bu seslerle oynamaya başladığı görülür. Çocukta içgüdüsel olarak var olan yaratma isteğinin, en kolay müzik eğitimi yolu ile geliştirilebileceği ifade edilir. Ancak yaratmanın, özgür ve esnek ortamlarda daha iyi gerçekleşeceği düşünülürse, çeşitli yöntemlere ve çocuğun kendini ifade etmesi, 
yeteneklerini keşfetmesi için ona uygun rahat koşulların sunulmasına de gereksinim vardır diyebiliriz. Bu durumda çocukların yoğun olan yaratıcılık ve estetik duygularının, erken gelişim dönemlerinde desteklenmemesinin, ileriki yıllarda yaratıcı, üretken ve çevrelerindeki güzellikleri algılayan bireyler olmalarını engelleyebileceğini düşünebiliriz. Yaratıcılığın gelişmesinde, özgüven önemli bir rol oynamaktadır (Ulutaş ve Ersoy, 2002: 27).

Müzik ile yaratıcılığın çok yakın ilişki içinde olması ve müziğin de özgüveni artırıcı etkisi olması nedeniyle, yapılan her doğaçlama bir cesaretin göstergesidir ve yaratıcılığın geliştirilmesinde müzik kullanılmalıdır sonucuna ulaşılabilir. Okulöncesi eğitimin temel amaçları, çocukların gelişim alanlarını ortak bir yetişme ortamında destekleyerek, Türkçeyi doğru ve güzel konuşma yetisine kavuşturacak biçimde, ilköğretime hazırlamak olarak tanımlanmıştır. Okulöncesinde müzik etkinliklerinin amaçları ise iletişim, farkında olma ve dil gelişimi ile ilgili amaçlar, fiziksel gelişim ile ilgili amaçlar, zihinsel gelişim ile ilgili amaçlar, yaratıcılık ve duygusal gelişim ile ilgili amaçlar biçiminde sıralanmaktadır. Çocuğa, estetik duygularını geliştirecek biçimde temel müzik becerilerinin kazandırılması ve müziğin eğitsel araç olarak kullanımı da okulöncesi müzik etkinliklerinin amacını oluşturmaktadır. Okulöncesi eğitimin temel ilkelerine dayanarak, müzik etkinliklerinin, çocuğun ve ailenin katılımına olanak verecek biçimde, çocuğun ilgi ve gereksinimlerine uygun ortamlarda, oyunlaştırılarak ve çocuğun yaparak öğrenmesine olanak verecek ve gelişim alanlarını destekleyecek biçimde hazırlanması gerekir. $\mathrm{Bu}$ nedenle okulöncesi eğitim programlarında müzik etkinlikleri çocuk merkezli olmalı ve yaparak-yaşayarak öğrenme ilkesini temel almalıdır (Uçan, 2001: 13).

Okul öncesi eğitimde, çocuğun hızlı gelişmesi ve ilgilerinin hızla değişmesi de dikkate alınarak eğitim etkinliklerinin etkili bir biçimde planlanması gerekmektedir. $\mathrm{Bu}$ bağlamda, okulöncesi öğretmeni, eğitimi daha nitelikli bir düzeye getirmek için yıllık ve günlük planlar hazırlamakla yükümlü olduğu söylenmektedir. Okulöncesi eğitim kurumlarında uygulanan, günlük etkinlik programında, müzik etkinliklerinin, çocukların ses ve ritimleri tanımaları, duygu ve düşüncelerini müzikli drama ve dans yoluyla ifade etmeleri, paylaşma, bir gruba ait olma, güven ve başarı duygusu kazanmaları açılarından, yardımcı olduğu, araştırmacılar tarafından söylenmektedir. Bu nedenle, okulöncesi müzik eğitiminin, çocukların davranışlarını geliştirmeye yardım edecek nitelikte planlanması son 
derece önemlidir denilebilir. Okulöncesinde, planlanan eğitim durumları, seçilen hedefleri kazandıracak nitelikte olmalı, farklı yöntem, teknik ve materyallere yer verilmeli, çocukların gelişim düzeylerine uygun, ilgi çekici, yaratıcılığ 1 destekleyici ve eğlendirici olmalıdır. Etkinlikler açıklanırken kullanılacak araç-gereçlerin ayrıca belirtilmesi gerekmektedir. Bunlar yeri geldikçe etkinlikler içinde belirtilmelidir. Bir etkinlikten diğer etkinliğe geçerken etkinlikler arasında bağlantılar kurulmasına dikkat edilmelidir. Eğitim durumları düzenlenirken etkinliklerin türleştirilmesine ve birden fazla etkinliğin bir arada ele alınmasına özen gösterilmelidir. Öğretmen, planım hazırlarken aldığı hedefe uygun olarak birden fazla etkinliği bir araya getirebilir (MEB, 2002: 44).

$\mathrm{Bu}$ bağlamda, müzik etkinlikleri diğer etkinliklerle birlikte ele alınabilecek en uygun etkinliktir. Müzik etkinlikleri diğer grup etkinliklerinden olan; Türkçe dil etkinliğinde, müzikli öykü, parmak oyunu, oyun etkinliğinde, müzikli oyunlar biçiminde kullanılabilir. Aynı biçimde, müzik etkinliklerinin drama, sanat eğitimi, okuma yazmaya hazırlık çalışmaları, hareket eğitimi ve fen doğa çalışmalarıyla birlikte kullanılması olanaklıdır. Bu nedenle, müzik etkinliklerini planlanırken diğer etkinlikler de dikkate alınmalı; müzik etkinliklerinden ortak bir payda olarak yararlanılmalıdır. Bu ortamı da öğretmenin gerçekleştireceği müzik etkinliği yaratabilir. Müzik köşesi anasınıfında bulunması zorunlu olan köşelerden biridir. İlgi çekici bir şekilde planlanmış bir müzik köşesi çocukların ilgisini çekerek müzikle oynamalarını sağlar. Müzik aletlerinin çeşitliliğinin, müziğin anasınıfı çocuklarının hayatına girmesinde önemli bir rolü olduğunu belirtebiliriz. Müzik köşesi her zaman aktif olmalı ve zaman zaman materyallerin yerleri değiştirilerek yenilenmelidir. Müzik köşesinde bulunması gereken materyaller; farklı boyutlarda davullar, tef, zilli tef, çelik üçgen, farklı özelliklerde marakaslar, zımpara bloklar, büyük ziller, gong, el zili, bilek zili, ksilefon, metalofon, kastanyet, ritim sopaları, tahta kaşıklar, tırtır, borular, mızıka, flüt, melodika, gitar, org, piyano, saz gibi gerçek enstrümanlar veya oyuncak enstrümanlar, ses kaydı yapabilen müzik seti, kaset ve CD'ler, yaratıcı dans için kullanılabilecek tül, kurdele ve flamalar, ayrıca ses çıkaran her şey bu köşede bulundurulabilir (Sığırtmaç, 2005: 88).

Öğretmen bu köşede oynamak isteyen çocuklara doğru rehberlik etmelidir. Çünkü hangi materyalin ne şekilde kullanılacağını bilen çocuk nitelikli sesler çıartmaya başlayacak, en azından böyle bir gayretin içine girecektir. Buna göre öğretmen, çocukların, çoklu zekâ 
kuramı içinde yer alan, müziksel ve ritmik zekâlarını (sesler, notalar, ritimlerle düşünme, farklı sesleri tanıma ve yeni sesler ritimler üretme, ritmik ve tonal kavramları tanıma ve kullanma, çevreden gelen seslere ve müzik yeteneğine karşı duyarlı olabilme yeteneği) ortaya çıartabilecek şekilde eğitim ortamı ve eğitim durumu hazırlamalı. Bu bağlamda, okulöncesi eğitim programının her aşamasında, etkin olarak görev yapan öğretmenler, programların başarıyla uygulanmasında en temel öğe konumundadırlar denilebilir. "Soyut bir sanat olarak bilinen müzikten okulöncesi eğitimde yararlanmanın ve yaratıcı çocuklar yetiştirmenin etkin yolu müziği çocuğa yaşatmaktır" (Morgül, 2001: 7).

Okulöncesi öğretmeninin, müziği eğitsel amaçlara ulaşmak için araç olarak kullanırken ilk yapacağ iş̧, müziği sevdirme ve yaşatma yoluna gitmesidir. Yaratıcı çocuklar yetiştirmede, etkili bir araç olan müzik etkinliklerinin, çocuğa sevdirilmesi ve çocukların müzik etkinliğine istekli biçimde katılımlarını sağlamanın, okulöncesi öğretmeninin kendi donanımıla da ilgili olduğu ifade edilebilir. Okulöncesi öğretmeni, her çocuğun özellikle ilgi duyduğu müzik etkinliğiyle uğraşmasına ortam hazırlamalı ve çocuğun her türlü müzik etkinliğiyle ilgilenmesini sağlayabilmelidir. Çocuğun müzikle ilgilenmesine, yeteneği doğrultusunda geliştirilmesine ve tümüyle müziği sevmesine elverişli bir ortam hazırlamak gerekmektedir. Müzik etkinliklerinde, öğretmenin; motive edici, planlayıcı, eşlik edici ve gözlemci niteliklere sahip olması gerekmektedir (Öztürk, 2002: 67).

$\mathrm{Bu}$ nitelikler şöyle açıklanabilir: Planlayıcıların, müzikal bir deneyimin planlanması, hazırlık, uygulama ve değişkenlik yaratma aşamalarını içeren bir nitelik olduğu belirtilir. Hazırlık aşaması, amacın belirlendiği, hangi çalışmanın uygulanacağı ve çalışmada gerekli malzemelerin oluşturulduğu aşamaları kapsamaktadır. Eşlik edicilik, müzik etkinliklerinde öğretmenin, çocuklara eşlik edici özelliğe sahip olabilmesi şeklinde ifade edilebilir. Müzik etkinliğinde öğretmen çocuklar için müzik yapmaktan çok çocuklarla müziği paylaşmayı amaçlamalıdır. Öğretmenin içinde bulunduğu müzik etkinliğinde, çocuklarla birlikte zevk almayı bilmesini ifade eder. Gözlemcilik, öğretmenin, müzik etkinliğini uygularken, "Çocuklar etkinliğe en fazla ne zaman katıldılar?", Çalışmanın hangi bölümü çocukların daha çok ilgilerini çekti?", "Çocuklar müzik etkinliğini nasıl hissettiler?" gibi sorulara yanıt arayacak nitelikte olması denilebilir. Motive ediciliğin ise öğretmenin müzik etkinliklerinde, çocukların çok yönlü eğitsel gereksinimlerini karşılayacak donanıma, düşünce sistemini geliştirici 
sorulara, çocukların aktif katılımlarını sağlayacak özelliğe sahip olması şeklinde tanımlanabilir.

\section{SONUÇ VE ÖNERILER}

Okulöncesi eğitim kurumlan, müzik sanatçısı yetiştirme amacıyla eğitim yapan kurumlar olmadığı gibi okulöncesi öğretmeni de müzik sanatçısı yetiştirecek biçimde bir müzik eğitimi vermekle görevli değildir. "Öğretmenden beklenen, çocuğun doğuştan eğilimli olduğu müziğe ilgisini arttırması ve bu ilgiyi beslemesidir " (Sun ve Seyrek, 1998: 31).

Öğretmen bu kapsamda çocukların var olan yeteneğini, bulunduğu düzeyden bir üst düzeye çıkarmaya çalışmalı ve böylece her çocuğa olumlu müzik yaşantıları sunmalıdır denilebilir. Ersoy'a (2003:

43) göre; "bir öğretmenin müzik etkinliklerini başarıla gerçekleştirebilmesi için müzikle ilgili genel kültüre ve temel müzik bilgisine, bildiklerini uygulama gücüne sahip olması gerekir. ', $\mathrm{Bu}$ bağlamda okulöncesi eğitimde müzik etkinliklerinin istenilen biçimde gerçekleşebilmesi, öğretmenlerin müzik eğitimi konusundaki niteliklerine ve yeterlik alanlarına bağlıdır diyebiliriz. Bu araştırma, okulöncesi öğretmenlerinin müzik etkinliklerini iyileştirme fikri düşünülerek yapılmıştır. Planlı programlı eğitimin ilk aşaması olan anasınıfı, günümüzde önemi yeni yeni anlaşılan bir süreçtir. Anasınıfı yaş grubu çocuklarının gelişim özellikleri incelendiğinde, anasınıfı programı daha bir önem kazanmaktadır. Bu programın en önemli amacının, çocukların beden, zihin, dil, duygusal, sosyal gelişiminin desteklenmesi için alışkanlık ve davranış kazandırmak olduğu belirtilmiştir. Bir günlük anasınıfı eğitimi programında müziğin, serbest zaman etkinliklerinde, sanata ait ilgi köşesi içinde müzik köşesi olarak, ana başlıklar içinde de müzik etkinliği olarak yer aldığı belirtilmektedir. $\mathrm{Bu}$ bağlamda, Müziğin bir günlük eğitim planında yer aldığı zaman dilimi, öğretmen tarafından bilinçli ve verimli kullandığında davranış ve alışkanlık kazandırma amacına ulaşılır düşüncesinden bakıldığında anasınıfı öğretmeninin çocuk gelişimi ile ilgili donanımının yanı sıra müzik eğitimine yönelik belirli bir yeterliliğe ve bu yeterliliği doğru şekilde kullanma becerisine sahip olması gerekir diyebiliriz. Nitelikli bir müzik eğitimi/etkinliği gerçekleştirmesi için bir çalgıyı kullanabilme, nota okuyabilme gibi bazı müziksel yeterliliklere sahip olması ve sahip olduğu yeterlilikleri performansa dönüştürmesi gereken anasınıfı öğretmenlerinin, bu yeterliliklere ne oranda sahip oldukları 
bilinmemektedir. Etkili bir eğitim aracı olarak kullanılması gereken müziğin, anasınıfı öğretmenleri tarafından birçok kez şarkı söyleme etkinliği ile sınırlı kalabildiği gözlemlerinden hareketle, etkili bir eğitim aracı olan müzikten, anasınıfı ortamında yeterince faydalanamama gibi bir durum ile karşı karşıya gelindiği düşünülmektedir. $\mathrm{Bu}$ durum Okulöncesi eğitiminin gerekliliğinin, öneminin vurgulandığı, yaygınlaştırılmaya çalışıldığ 1 günümüzde, yaygın ve nitelikli bir okul öncesi eğitimin bir ayağının eksik kalması anlamına gelmektedir. Böyle bir durumda da "Anasınıfı öğretmenleri kendilerini müzik öğretimine yönelik ne kadar yeterli buluyorlar?" ve "Anasınıfı öğretmenlerinin müzik eğitimi ortamına yönelik düşünceleri nelerdir?" sorularına verilecek cevaplar oldukça anlamlı olacaktır. Anasınıfı öğretmeni yetiştiren lisans programlarında yer alan, müzik eğitimi dersinin içerik ve süre olarak gözden geçirilmesi şarttır. Anasınıfı öğretmenlerinin müzik öğretimine yönelik, ihtiyaç duydukları eğitim başlıklarının belirlenip, hizmet içi eğitim çalışmalarına 1şık tutması oldukça önemlidir. Anasınıfı öğretmenlerinin, anasınıfında müzik öğretimine yönelik ihtiyaç duydukları materyallerin belirlenip, bu konuda tüm anasınıflarında, gerekli standardizasyonun sağlanmasına yönelik çabalar gündeme gelmelidir. Anasınıfi öğretmenleri ve anasınıfında müzik öğretimi ile ilgili yapılacak araştırmalara, katkı sağlaması açısından, önemli rol oynamaktadırlar. Çocuklarımız, onların müzikal deneyimlerini sağlama ve yönlendirmede aktif rol alan bir öğretmenle müzik eğitimi alabilmeli, çocuğun duygusal, zihinsel, fiziksel ve estetik gelişim özellikleri göz önünde bulundurulmalı, müzik yoluyla müzik öğretilmeli, müziğe öğretim programının bir parçası olarak bakılmalı ve programın anlamlı bir bölümü haline gelmesi için üniteler göz önünde bulundurulmalı, hem yetenek ve hem de anlamayı sağlayacak davranış tarzında müzik öğretilmeye çalışılmalıdır.

\section{KAYNAKÇA}

Akyüz, Y. (1994). Türk Eğitim Tarihi. İstanbul: Kültür Koleji Yayınlan Aral, N., Kandır, A. ve Yaşar, M.C. (2003) Okul Öncesi Eğitim 1. 2. Bask1. İstanbul: Ya-pa Yayınc1lık.

Arslan, A. (2005). Erken Çocuklukta Müziğin Önemi ve Şarkı Öğretimi. Erken Çocuklukta Gelişim ve Eğitimde Yeni Yaklaşımlar 2. İstanbul: Moıpa Yayıncılık. 
Artan, İ, Balat, G.U. (2001). "Anaokuluna devam eden dört ve alt yaş grubu çocukların şarkı söyleme ile ilgili düşüncelerinin incelenmesi”. Ankara: Gazi Üniversitesi Kastamonu Eğitim Dergisi. Cilt:9, Sayı:2

Bilir, Ş, Bal, S, artan, İ. (1993). Anaokuluna devam eden 5-7 yaş grubundaki ileri derecede işitme özürlü çocukların işitsel algı gelişimlerinin incelenmesi. Ankara: Başbakanlık Aile ve Sosyal Araştırmalar Gn. Md. Aile ve Toplum Dergisi.

Çilden, Ş. (2001). Müzik, Çocuk Gelişimi ve Öğrenme. Gazi Üniversitesi Gazi Eğitim Fakültesi Dergisi, 21 (1).

Ersoy, Ö. (2003). Müzik Etkinliklerinde Öğretmenin Rolü Müziğin Okulöncesi Eğitimde Kullanılması. Ankara: Kök Yayıncılık.

Kamacıoğlu, F. (1990). Müzik Eğitiminde Arayışlar. İstanbul: Marmara Üniversitesi Atatürk Eğitim Fakültesi Eğitim Bilimleri Dergisi.

Karasar, N. (2006) Bilimsel Araştırma Yöntemi. Ankara: Nobel Yayın Dağıtım.

Karşal, E. (2005). Matematik ve Müzik. Müzik ve Bilim Dergisi. Uluslar arası Hakemli Bilimsel Müzik Dergisi.

Kurudayığlu, A. G. M. (2003). Konuşma Eğimi ve Konuşma Becerisini Geliştirmeye Yönelik Etkinlikler. Türklük Bilimi Araştırmaları.

Morgül, M. (2001). İlk Çocuklukta Müzik Nasıl Öğretilir Ankara: Kök Yayınları.

MEB, (Milli Eğitim Bakanlığı). (2002). Talim ve Terbiye Kurulu Başkanlığının 31.05.2002 Tarih ve 270 Sayılı Kararı, Tebliğler Dergisi.

Oğuzkan, Ş. ve Oral, G. (1991.) Okul Öncesi Eğitimi. M.E. B. Devlet Kitapları Ankara: Gazi Üniversitesi Teknik Eğitim Fakültesi Matbaas1.

Oktay, A. (2000). Yaşamın Sihirli Yılları. Okul Öncesi Dönem. Epsilon Yayınları.

Öztürk, A. (2002). Okul Öncesi Eğitimde Müzik. İstanbul: Morpa Kültür Yayınları.

Sığırtmaç, A.D. (2005) Okulöncesi Dönemde Müzik Eğitimi. İstanbul: Kare Yayınları. 
Sun, M., Seyrek, H. (1998). Okul Öncesi Eğitiminde Müzik. İzmir: Mey Müzik Eserleri Yayınları.

Sungurtekin, Ş. (2001). "Uygulamal Çevre Eğitimi Projesi" Kapsaminda Ana ve Illköğretim Okullarında "Müzik Yoluyla Çevre Eğitimi”. Bursa: Uludağ Üniversitesi Eğitim Fakültesi Dergisi.

Uçan, A. (2001) "Okulöncesi Müzik Eğitimi ve Programı”, Müzik Öğretimi. Eskişehir: Anadolu Üniversitesi. Açıöğretim Fakültesi Yayınları.

Ulutaş, 1., Ersoy, Ö. (2002). Okul Öncesi Dönemde Sanat Eğitimi. Gazi Üniversitesi Kastamonu Eğitim Dergisi.

Varol, N. (1997). Bilgisayar Destekli Eğitim.

Yıldırım, A. Şimşek, H. (2006). Sosyal Bilimlerde Nitel Araştırma Yöntemleri. Ankara: Seçkin Yayınları 